\title{
Sistem Pengendali Mesin Tenun GA615
}

\author{
Dwi Cahyo Mahardika ${ }^{1}$, Deddy Susilo ${ }^{2}$, Darmawan Utomo ${ }^{3}$ \\ 1,2Program Studi Teknik Elektro, \\ Fakultas Teknik Elektronika dan Komputer, \\ Universitas Kristen Satya Wacana, Salatiga \\ 1dwicahyomahardika91@gmail.com,2deddy.susilo@staff.uksw.edu, \\ 3Program Studi Sistem Komputer, \\ Fakultas Teknik Elektronika dan Komputer, \\ Universitas Kristen Satya Wacana, Salatiga \\ darmawan@staff.uksw.edu
}

\begin{abstract}
Ringkasan
Sistem pengendali mesin tenun GA615 ini dibuat dengan tujuan untuk mengganti sistem pengendali yang lama di PT. Panca Bintang Tunggal Sejahtera, karena banyak yang sudah tidak dapat bekerja dengan baik. Sistem yang diusulkan menggunakan mikrokontroler ATMEGA 328P sebagai pengendali utama. Cara kerja sistem adalah menunggu masukan dari operator melalui lima buah tombol yaitu maju, mundur, jogging, start, dan stop. Terdapat dua buah proximity sensor Autonics PR18-5DN untuk menentukan batas depan dan belakang. Tombol masukan dan proximity sensor tersebut diolah dalam sebuah mikrokontroler yang kemudian didapat keluaran untuk menggerakan motor AC tiga fasa sebagai penggerak utama serta rem elektromagnetik sebagai komponen pengereman, melalui relay dan kontaktor. Pengujian sistem yang telah dilakukan sebanyak 30 kali, didapatkan prosentase keberhasilan untuk masing - masing tombol. Untuk tombol maju, mundur, jogging, dan start prosentase keberhasilan 100\%. Sedangkan untuk tombol stop prosentase keberhasilan $93.33 \%$, ini disebabkan respon sistem pengereman yang kurang cepat dalam melakukan pengereman saat putaran motor sangat cepat, sehingga saat berhenti masih terlalu maju.
\end{abstract}

Kata kunci: pengendali mesin tenun GA615, mikrokontroler, proximity sensor

\section{Pendahuluan}

Mesin merupakan perkakas untuk menggerakkan atau membuat sesuatu yang dijalankan dengan roda, digerakkan oleh tenaga manusia atau motor penggerak, menggunakan bahan bakar minyak atau tenaga alam. Sedangkan Tenun adalah hasil kerajinan yang berupa bahan (kain) yang dibuat dari benang seperti kapas dan sutra, dengan cara memasuk-masukkan pakan secara melintang pada lungsin. Sehingga, Mesin Tenun merupakan suatu alat yang digerakkan oleh motor penggerak atau tenaga manusia untuk menghasilkan suatu kerajinan yang berupa kain. Penunjang kemajuan di bidang industri adalah berkembangnya sistem kontrol untuk mengatur mesin-mesin yang digunakan dalam proses industri. Sistem kontrol ini berfungsi untuk memonitoring kondisi tertentu dalam rangkaian atau mesin tersebut supaya dapat bekerja sesuai dengan yang diharapkan. PT. Panca Bintang Tunggal Sejahtera yang berlokasi di Manang, Grogol, Sukoharjo, merupakan perusahaan yang bergerak pada bidang industri 
tekstil. Contoh mesin tenun yang digunakan pada PT. Panca Bintang Tunggal Sejahtera dapat dilihat pada Gambar 1 (a) dan (b).

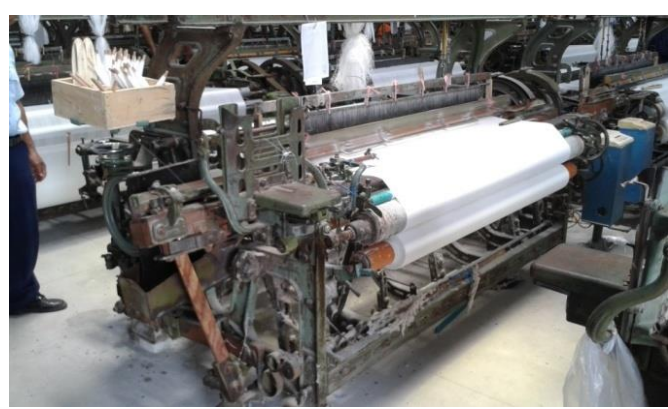

(a)

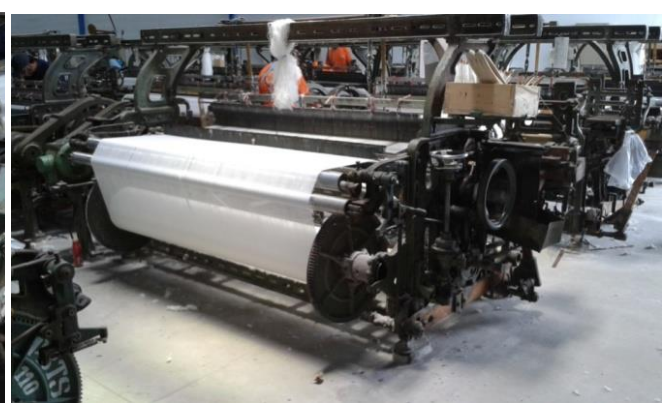

(b)

Gambar 1. Mesin Tenun GA615 (a) Tampak belakang, (b) Tampak depan.

Untuk meningkatkan produktivitas, PT. Panca Bintang Tunggal Sejahtera telah mendatangkan sejumlah mesin tenun bertipe GA615 dari RRT sejumlah 192 mesin, tetapi sistem pengendali elektronika dari mesin tersebut banyak yang sudah tidak dapat berfungsi. Hanya ada 90 mesin yang masih dapat bekerja. Tidak disertakan skematiknya saat mendatangkan, menyebabkan sulit untuk dibenahi. Oleh karena itu, pada artikel ini akan dibuat sebuah sistem pengendali baru menggunakan mikrokontroler, yang mampu menggantikan sistem pengendali lama, tentunya dengan biaya yang tidak terlalu mahal. Sehingga produktivitas akan meningkat karena ada pertambahan mesin tenun yang dapat berfungsi dengan biaya minimal.

Pembahasan dimulai dengan deskripsi sistem, meliputi cara kerja sistem, perancangan perangkat keras, dan perancangan perangkat lunak. Kemudian dilanjutkan dengan ilustrasi dan hasil pengujian dan diakhiri dengan kesimpulan.

\section{Deskripsi Sistem}

Sistem pengendali mesin tenun GA615 terdiri dari beberapa masukan dan keluaran. Masukan terdiri dari 5 buah tombol dan 2 buah proximity sensor[1]. Sedangkan keluaran berupa relay dan kontaktor yang akan mengaktifkan motor $A C$ tiga fasa sebagai penggerak utama serta sistem pengereman. Masukan ini kemudian diolah oleh mikrokontroler. Hasil dari olahan masukan tersebut digunakan untuk mengendalikan keluaran. Deskripsi sistem dapat dilihat pada diagram blok yang ditunjukkan pada Gambar 2.

\subsection{Cara kerja sistem}

Saat awal, sistem kelistrikan dihidupkan, kemudian setelah kelistrikan hidup, mesin siap digunakan. Mesin bekerja dengan cara menunggu penekanan tombol dari operator. Ada lima buah tombol, yaitu maju, mundur, jogging, start, stop, serta dua buah proximity sensor, yaitu sensor batas depan dan belakang.

Ketika ditekan tombol maju, maka motor akan berputar ke arah operator sejauh satu langkah, satu langkah ini ditentukan oleh pewaktuan. Tombol maju dapat ditekan selama sensor batas depan belum mendeteksi logam. 


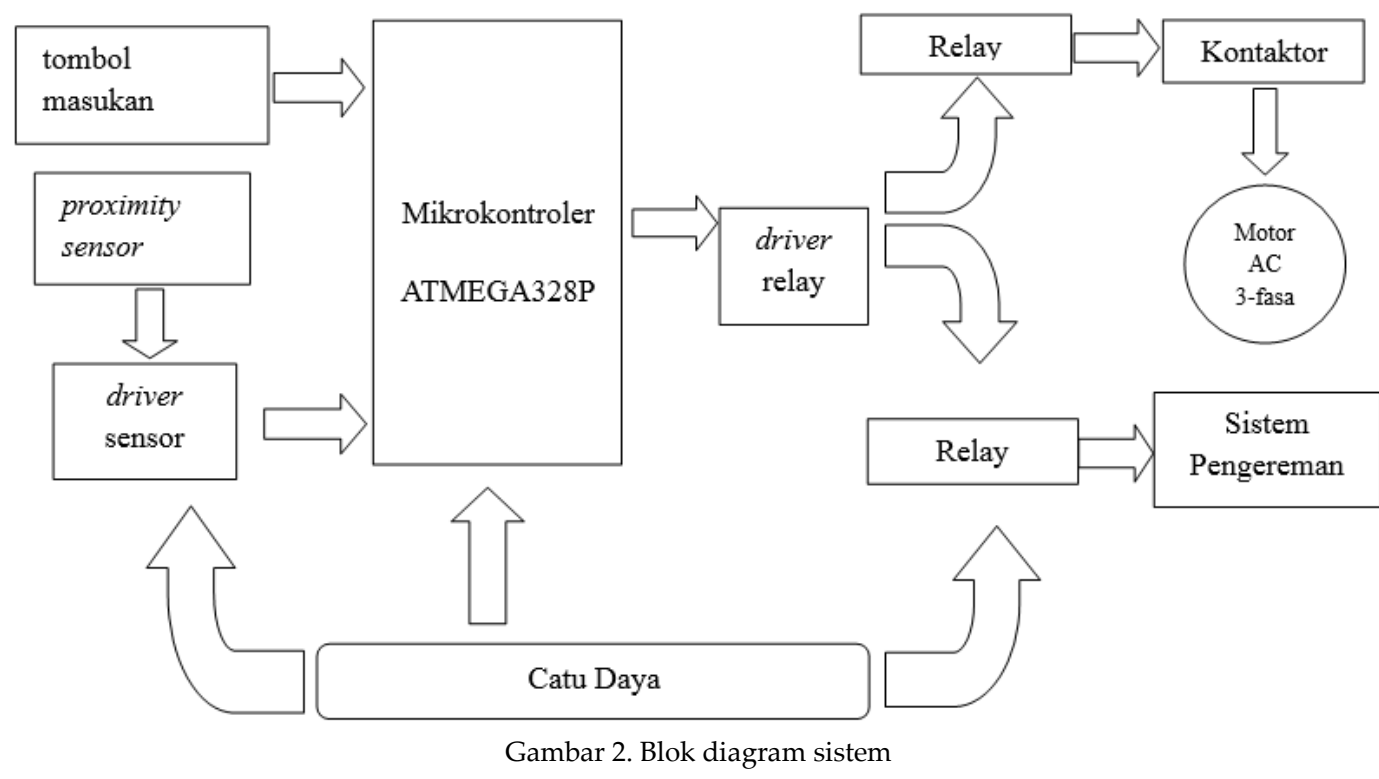

Jika ditekan tombol mundur, maka motor akan berputar ke arah menjauhi operator sejauh satu langkah, satu langkah ini ditentukan dengan pewaktuan. Tombol mundur dapat ditekan selama sensor batas belakang belum mendeteksi logam.

Jika ditekan tombol jogging, maka sistem akan memeriksa sensor batas belakang sudah mendeteksi logam atau belum, jika sudah mendeteksi, maka motor langsung berputar sejauh satu putaran kembali lagi ke posisi semula, jika belum mendeteksi, maka operator diminta untuk menekan tombol mundur sampai sensor batas belakang mendeteksi logam.

Jika ditekan tombol start, maka sistem akan memeriksa sensor batas belakang sudah mendeteksi atau belum, jika sudah mendeteksi, maka motor dapat langsung berputar. Jika belum mendeteksi, maka diperlukan penekanan tombol mundur sampai sensor batas belakang mendeteksi.

Jika ditekan tombol stop, maka sistem akan memeriksa, motor dalam keadaan berputar ke depan atau tidak, jika motor dalam keadaan berputar, maka motor langsung dihentikan, lalu dilakukan pengereman saat sensor batas belakang mendeteksi.

Sistem pengereman, menggunakan sistem rem elektromagnetik, yang akan aktif ketika dipicu dengan tegangan 75-110 VDC. Dengan tujuan menghentikan putaran motor seketika itu juga.

\subsection{Perancangan perangkat keras}

Perancangan perangkat keras terdiri dari beberapa modul, yaitu modul mikrokontroler, tombol masukan, driver sensor, driver relay, serta pengkabelan kontaktor.

a. Modul Mikrokontroler

Mikrokontroler yang digunakan adalah ATMEGA328P, dengan untai pada Gambar 3.

b. Tombol masukan

Pada modul tombol masukan, digunakan lima buah tombol bertipe push-ON. Kelima tombol tersebut adalah Tombol Maju, Mundur, Jogging, Start dan Stop. Masing - masing tombol ini terhubung ke pin mikrokontroler dengan konfigurasi 
seperti pada Gambar 4. Dengan mengaktifkan fitur internal pull-up yang ada pada chip ATMEGA328P maka tidak perlu memakai resistor pull-up ataupun pull-down. Digunakan dioda pengaman untuk membatasi tegangan, jika mendapat tegangan negatif dari induksi/spike, maka akan dibuang ke ground melalui dioda D3, D5, D7, D9, dan D11, sedangkan jika mendapat tambahan tegangan, maka akan dibuang ke vcc melalui D4, D6, D8, D10, dan D12.

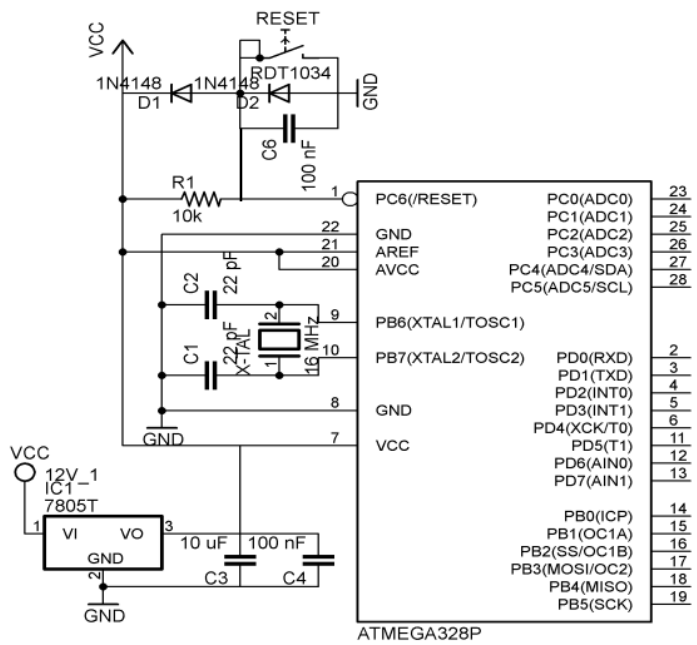

Gambar 3. Untai Modul Mikrokontroler.

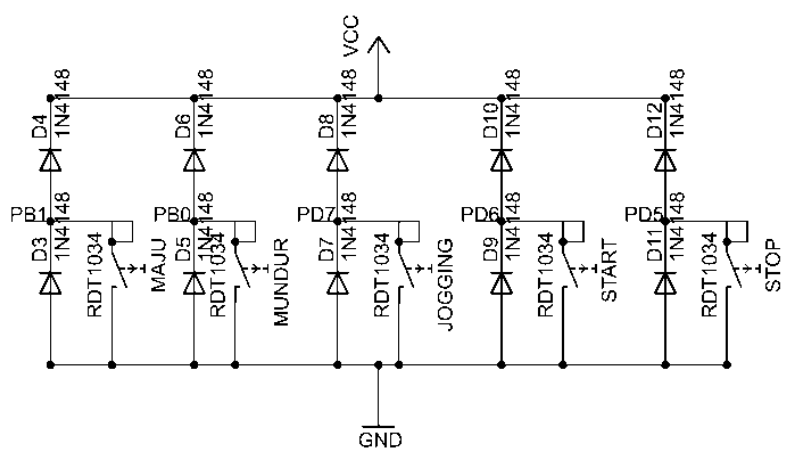

Gambar 4. Untai Tombol Masukan.

\section{c. Driver sensor}

Untuk membaca perubahan state output proximity sensor, digunakan MOSFET Nchannel dengan seri 2N7000. Output dari sensor masuk ke kaki Gate MOSFET yang sudah diberi resistor pull-up, kemudian input ke mikrokontroler diambil dari Drain MOSFET menuju ke pin PB4(sensor depan) dan PB3(sensor belakang). Dengan mengaktifkan fitur internal pull-up yang ada pada chip ATMEGA328P maka tidak perlu memakai resistor pull-up ataupun pull-down pada kaki input mikrokontroler[2]. Saat sensor tak mendeteksi logam, tegangan pada kaki Gate ditarik ke 12V (High), ini menyebabkan MOSFET aktif, kemudian tegangan pada Drain ditarik ke Ground (Low) maka menghasilkan logika '0' pada input mikrokontroler. Kemudian, saat sensor mendeteksi logam, tegangan pada kaki Gate ditarik ke Ground (Low), ini menyebabkan MOSFET tidak aktif, kemudian tegangan pada Drain ditarik ke 5V (High) maka menghasilkan logika ' 1 ' pada input mikrokontroler. Digunakan dioda pengaman untuk membatasi tegangan, jika mendapat tegangan negatif dari induksi/spike, maka akan dibuang ke ground melalui 
dioda D16 dan D18, sedangkan jika mendapat tambahan tegangan, maka akan dibuang ke vcc melalui D17 dan D19.

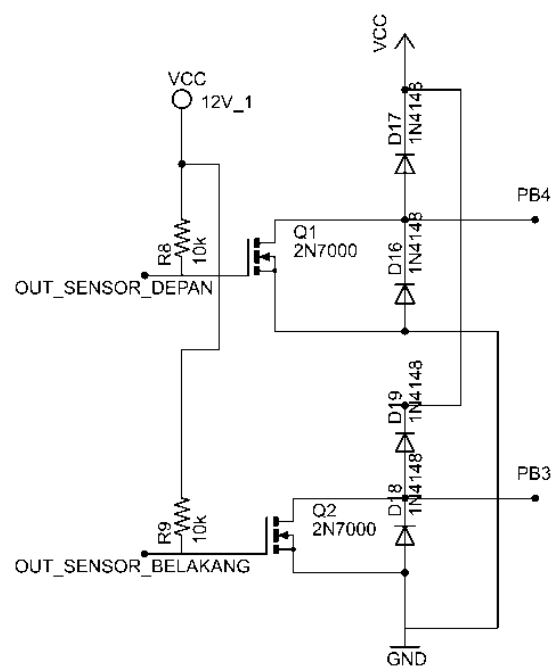

Gambar 5. Untai Driver Sensor.

d. Driver relay

Pada modul Driver Relay, digunakan IC Optocoupler PC817 untuk mengisolasi rangkaian antara mikrokontroler dengan relay. Dapat dilihat pada Gambar 6, bahwa ground-nya terpisah/beda dengan ground pada Gambar 5, ini bertujuan untuk memisahkan grounding pada sistem mikrokontroler dengan sistem relay, supaya arus pada mikrokontroler tidak terganggu oleh relay. Sedangkan untuk menggerakkan relay, digunakan IC ULN2003A. Output dari mikrokontroler, yaitu port PD2, PD3, dan PD4 masuk ke anoda dari IC Optocoupler. Saat input optocoupler high, ini menyebabkan phototransistor aktif, maka menghasilkan logika high pada kaki emiternya. Kemudian saat input optocoupler low, ini menyebabkan phototransistor tidak aktif, maka menghasilkan logika low pada kaki emiternya yang mana emiter ini terhubung dengan IC ULN2003A pada sisi input sesuai yang tertampil pada Gambar 6. Ketika, input ULN2003A high, maka akan menghasilkan output low. Sedangkan saat input ULN2003A low, maka akan menghasilkan output high.

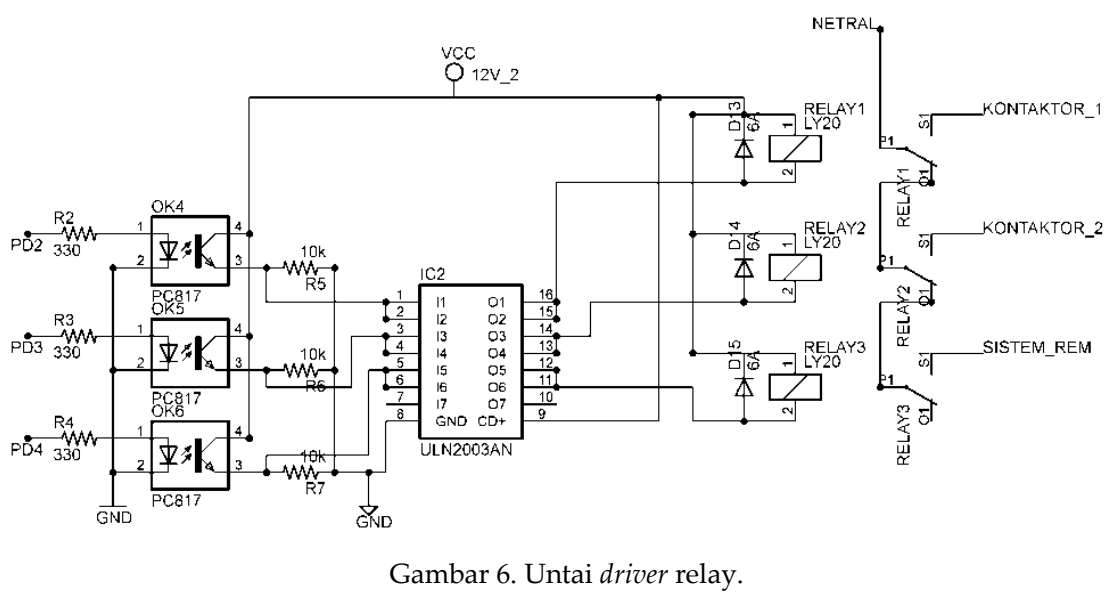


e. Pengkabelan kontaktor

Pengkabelan antara kontaktor dengan relay terdapat pada Gambar 7. Kontaktor yang digunakan merupakan produk dari Scneider seri LC1D09M7[3]. Kontaktor ini menggunakan tegangan koil 220 VAC. Pada Gambar 7, menggunakan dua buah kontaktor yang kemudian diberi nama K1 (Forward) dan K2 (Reverse). Label KONTAKTOR_1 dan KONTAKTOR_2 pada Gambar 7, terhubung dengan label KONTAKTOR_1 dan KONTAKTOR_2 pada Gambar 6. M merupakan Motor AC tiga fasa yang digunakan sebagai penggerak utama pada mesin tenun. R, S, T, merupakan sumber tegangan tiga fasa. $\mathrm{N}$ menunjukan kabel Netral. Untuk mengaktifkan kontaktor maka diperlukan tegangan fasa dengan netral, karena kontaktor tersebut menggunakan koil 220 VAC pada pin A1 dan A2. Terdapat 2 buah kontak bantu yaitu NO (Normally Open), dan NC (Normally Connect). Pin A2 (K1) terhubung dengan tegangan sumber fasa R. Pin A2 (K2) terhubung dengan tegangan sumber fasa S. Pin A1 (K1) terhubung pada NC (K2), kemudian dari NC (K2) ini terhubung dengan relay-1 pada Gambar 6. Pin A1 (K2) terhubung pada NC (K1), kemudian dari NC (K1) ini terhubung dengan relay-2 pada Gambar 6. [4]

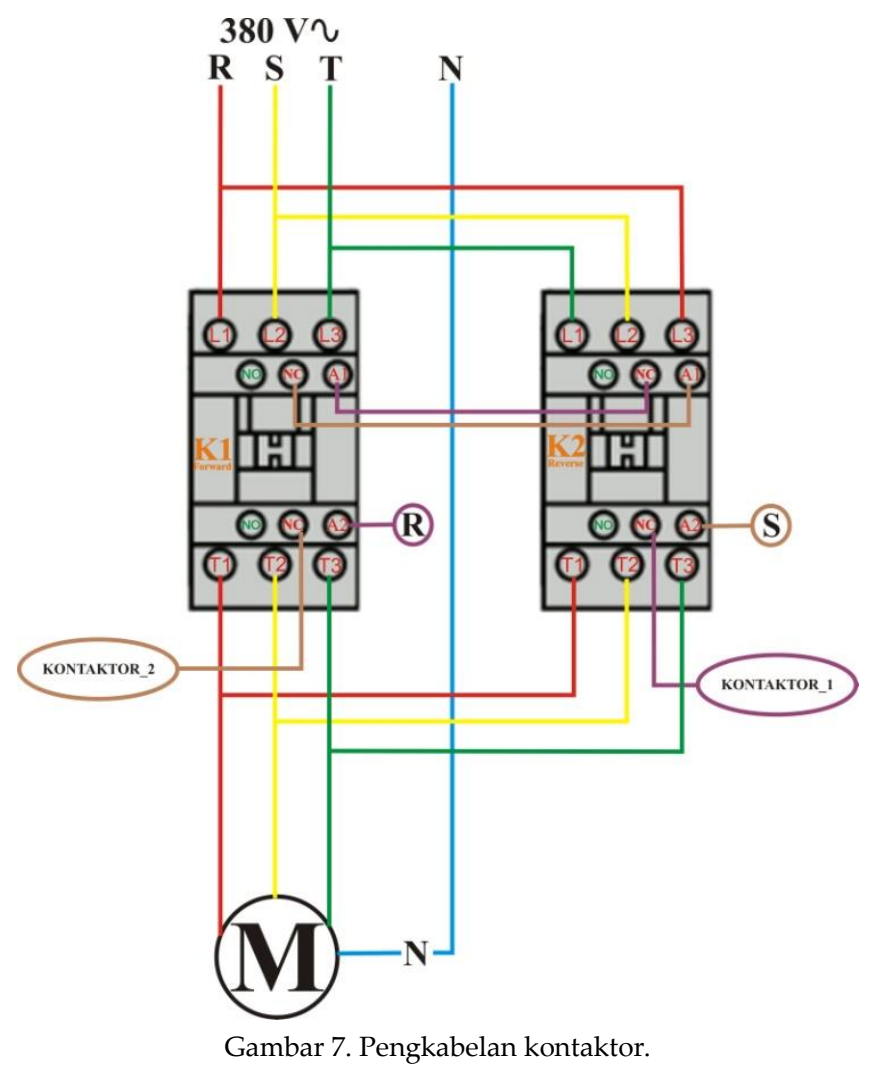

\subsection{Perancangan perangkat lunak}

Perangkat lunak digunakan untuk mengendalikan seluruh operasi sistem. Perangkat lunak ditulis dan di-compile menggunakan Arduino IDE 1.6 .5 yang kemudian di tanamkan ke mikrokontroler. Pada bagian ini akan dibahas garis besar program sistem yang direpresentasikan melalui diagram alir.

Untuk mengatur gerak dan pengereman motor, dibutuhkan tiga buah relay. Relay-1 merupakan relay yang digunakan untuk menghidupkan kontaktor arah maju (Forward), 
Relay-2 merupakan relay yang digunakan untuk menghidupkan kontaktor arah mundur (Reverse), sedangkan Relay-3 merupakan relay yang digunakan untuk mengaktifkan Rem. Sedangkan untuk sensor proximity dibutuhkan dua buah sensor, Sensor Belakang merupakan sensor yang digunakan untuk mengetahui batas belakang. Sensor Depan, merupakan sensor yang digunakan untuk mengetahui batas depan.

Proses kerja dari sistem pengendali mesin tenun dijelaskan sebagai berikut. Pada saat awal sistem dihidupkan, sistem menunggu masukan yang diberikan oleh operator dengan cara penekanan salah satu tombol. Masukan yang diberikan akan dibandingkan apakah Tombol Maju, Mundur, Jogging, Start, atau Stop.

a. Jika ditekan Tombol Maju, maka sistem akan membandingkan, apakah Sensor Depan mendeteksi, jika ya, maka akan kembali meminta masukan, jika tidak, maka akan menjalankan subrutin maju.

b. Jika ditekan Tombol Mundur, maka sistem akan membandingkan, apakah Sensor Belakang mendeteksi, jika ya, maka akan kembali meminta masukan, jika tidak, maka akan menjalankan subrutin mundur.

c. Jika ditekan Tombol Jogging, maka sistem akan membandingkan, apakah Sensor Belakang mendeteksi, jika ya, maka akan menjalankan subrutin jogging, jika tidak, maka akan kembali meminta masukan.

d. Jika ditekan Tombol Start, maka sistem akan membandingkan, apakah Sensor Belakang mendeteksi, jika ya, maka akan menjalankan subrutin start, jika tidak, maka akan kembali meminta masukan.

e. Jika ditekan Tombol Stop, maka sistem akan membandingkan, apakah Relay-1 hidup, jika ya, maka akan menjalankan subrutin stop, jika tidak, maka akan kembali meminta masukan.

Diagram alir program utama ditunjukkan pada Gambar 8. Diagram alir untuk masing - masing tombol disajikan dalam Gambar 9.

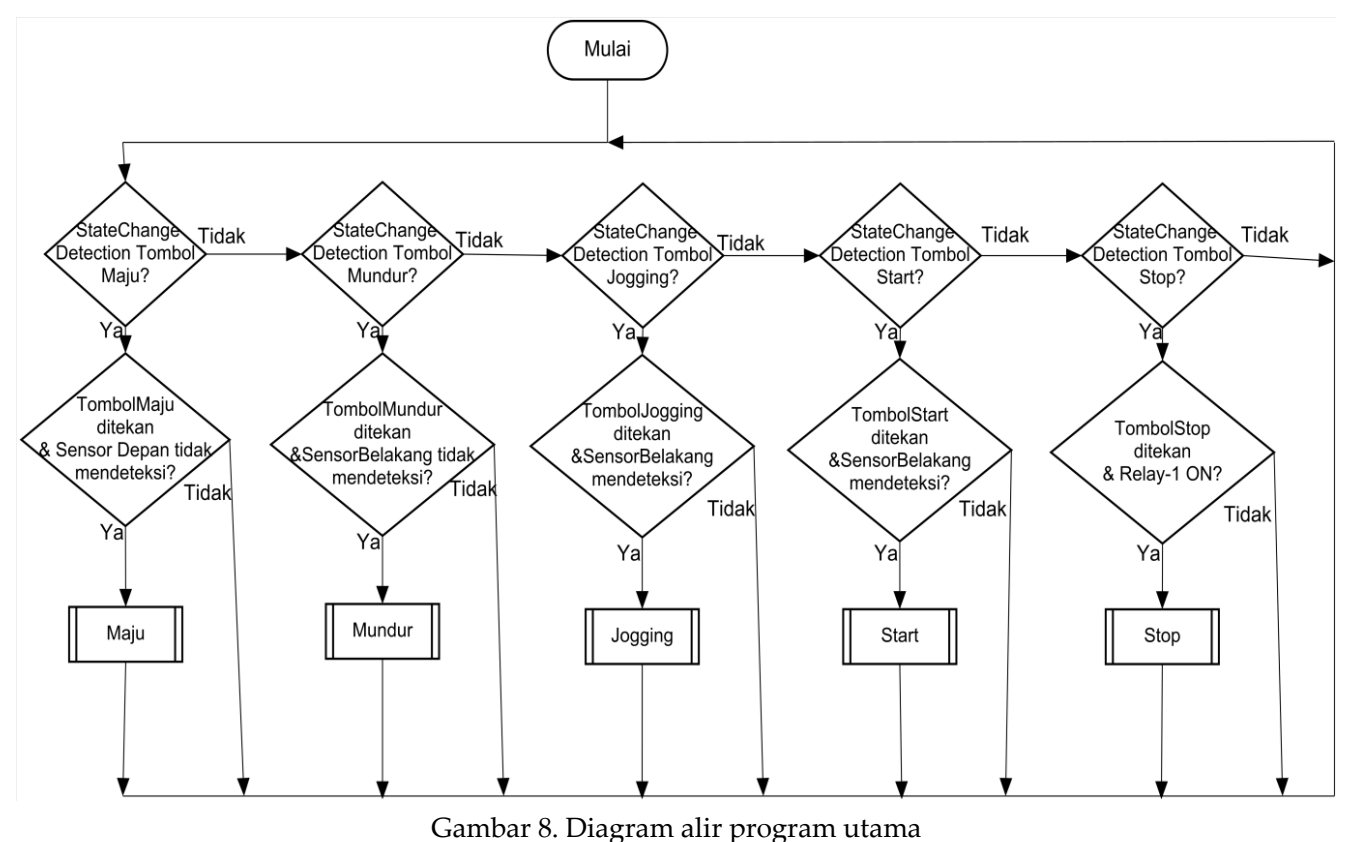




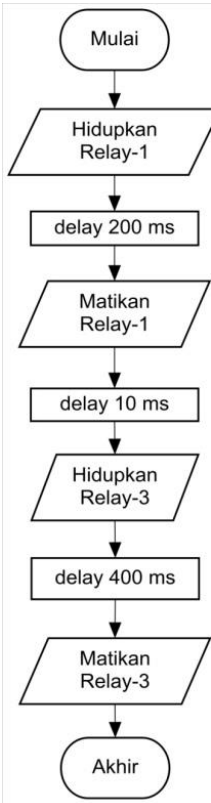

(a)

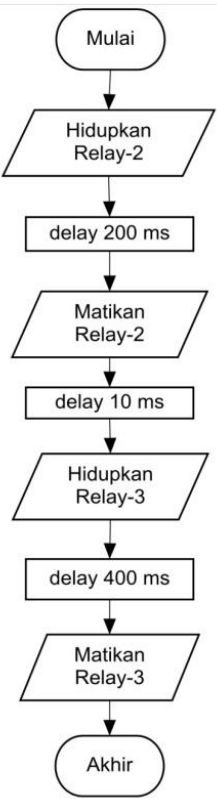

(b)
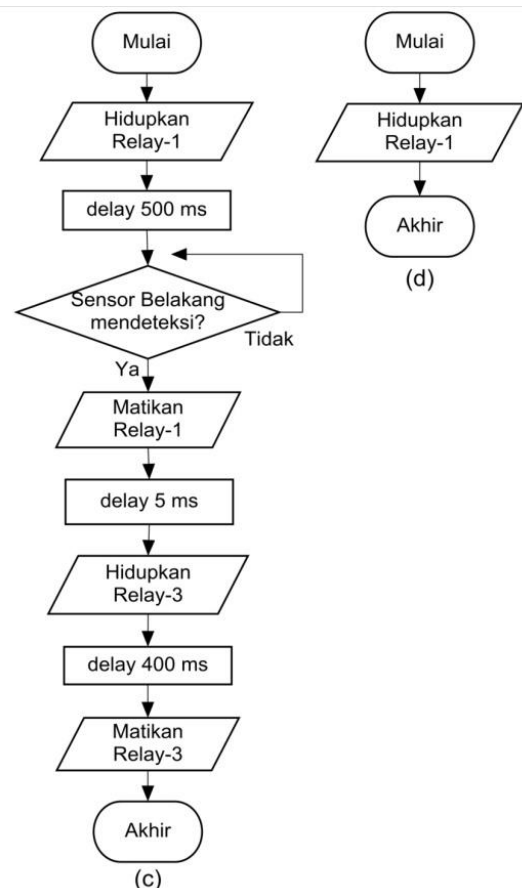

(d)

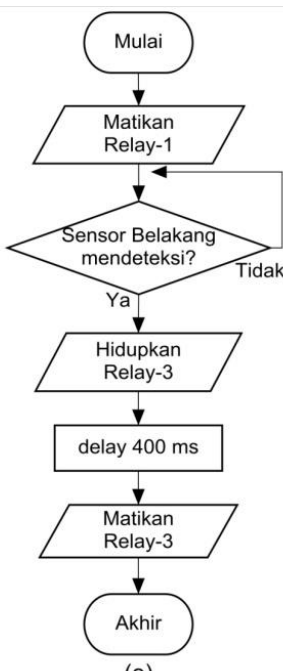

(e)

Gambar 9. Diagram Alir Maju(a), Mundur(b), Jogging(c), Start(d), Stop(e)

\section{Ilustrasi dan Hasil Pengujian}

Ilustrasi pengujian bertujuan untuk memberi gambaran pada tiap state/posisi dari sensor proximity dan logam.

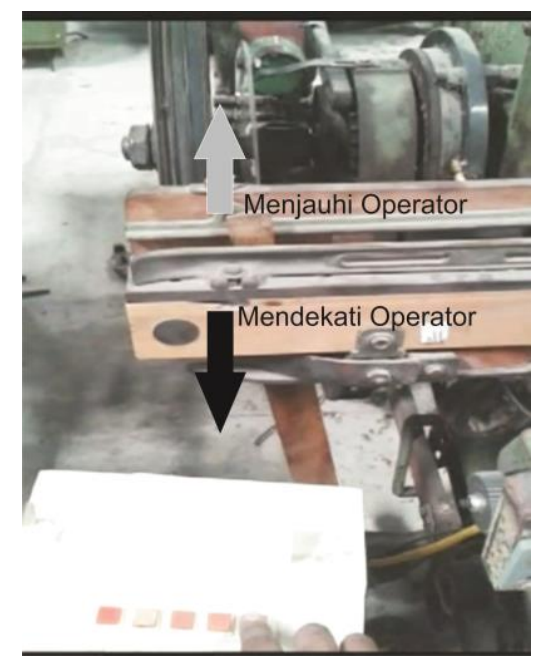

Gambar 10. Arah pergerakan motor.

Gambar 10, merupakan gambar arah pergerakan motor, ditunjukkan dengan anak panah. Anak panah yang berwarna hitam, menunjukkan pergerakan motor ke arah mendekati operator. Sedangkan anak panah yang berwarna abu - abu, menunjukkan pergerakan motor ke arah menjauhi operator.

Pada Gambar 11, bagian yang berwarna biru menunjukkan bahan logam yang nantinya akan dideteksi oleh sensor proximity. Bagian biru ini menempel pada lingkaran 
warna kuning, warna kuning ini berotasi. Tanda panah menunjukkan arah rotasi bagian yang berwarna kuning dan biru yaitu ke arah maju/forward. Bagian lingkaran yang berwarna merah, merupakan sensor proximity yang digunakan. Sensor ini tidak ikut berotasi seperti warna biru dan kuning. Ada dua sensor, yaitu sensor batas depan (ditandai dengan nomor 1), dan sensor batas belakang (ditandai dengan nomor 2).

Gambar 11, menunjukkan kondisi sensor batas belakang (2) mendeteksi logam, berarti saat ini motor tidak dapat bergerak ke arah mundur lagi, karena sudah mencapai batas belakang. Tetapi masih dapat bergerak ke arah maju/mendekati operator. Selain itu, kondisi ini juga merupakan syarat Tombol Jogging dan Start agar dapat bekerja, yaitu sensor batas belakang (2) mendeteksi logam dan juga sebagai syarat berhenti yaitu harus pada saat sensor batas belakang (2) mendeteksi logam. Gambar 12, merupakan gambar kondisi nyata pada mesin untuk ilustrasi pertama.

Gambar 13, menunjukkan kondisi kedua sensor tidak mendeteksi logam sama sekali, berarti saat ini dapat bergerak maju (mendekati operator) ataupun mundur (menjauhi operator), karena belum mencapai batas belakang/depan. Namun, pada kondisi ini, tombol jogging dan start tidak dapat bekerja sesuai prosedur, karena belum memenuhi persyaratan, seperti yang sudah dijelaskan pada bagian sebelumnya. Gambar 14, merupakan gambar kondisi nyata pada mesin untuk ilustrasi kedua.

Gambar 15, menunjukkan kondisi sensor batas depan mendeteksi logam, berarti saat ini motor tidak dapat bergerak ke arah maju (mendekati operator) lagi, karena sudah mencapai batas depan. Tetapi masih dapat bergerak ke arah mundur (menjauhi operator). Gambar 16, merupakan gambar kondisi nyata pada mesin untuk ilustrasi ketiga.

Hasil pengujian disajikan dalam Tabel 1. Dari hasil pengujian yang telah dilakukan sebanyak 30 kali, didapatkan prosentase keberhasilan untuk masing - masing tombol, yaitu untuk tombol Maju, Mundur, Jogging, dan Start 100\%, sedangkan untuk tombol Stop, didapatkan prosentase keberhasilan 93,33\%, dikarenakan terjadi dua kali kegagalan dalam berhenti. Kegagalan ini disebabkan mikrokontroler terkena spike sesaat sebelum melakukan pengereman.

Tabel 1. Hasil Pengujian tiap tombol.

\begin{tabular}{|c|c|c|c|c|c|}
\hline & $\begin{array}{c}\text { Tombol } \\
\text { Maju }\end{array}$ & $\begin{array}{c}\text { Tombol } \\
\text { Mundur }\end{array}$ & $\begin{array}{c}\text { Tombol } \\
\text { Jogging }\end{array}$ & $\begin{array}{c}\text { Tombol } \\
\text { Start }\end{array}$ & $\begin{array}{c}\text { Tombol } \\
\text { Stop }\end{array}$ \\
\hline Jumlah Berhasil $(\sqrt{ })$ & 30 & 30 & 30 & 30 & 28 \\
\hline Jumlah Gagal $(\times)$ & 0 & 0 & 0 & 0 & 2 \\
\hline Prosentase Keberhasilan & $100 \%$ & $100 \%$ & $100 \%$ & $100 \%$ & $93,33 \%$ \\
\hline
\end{tabular}




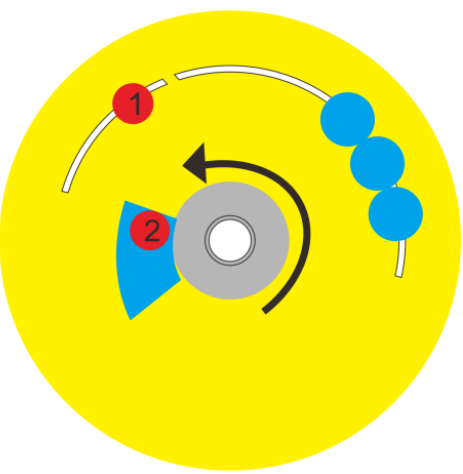

Gambar 11. Ilustrasi Pertama.

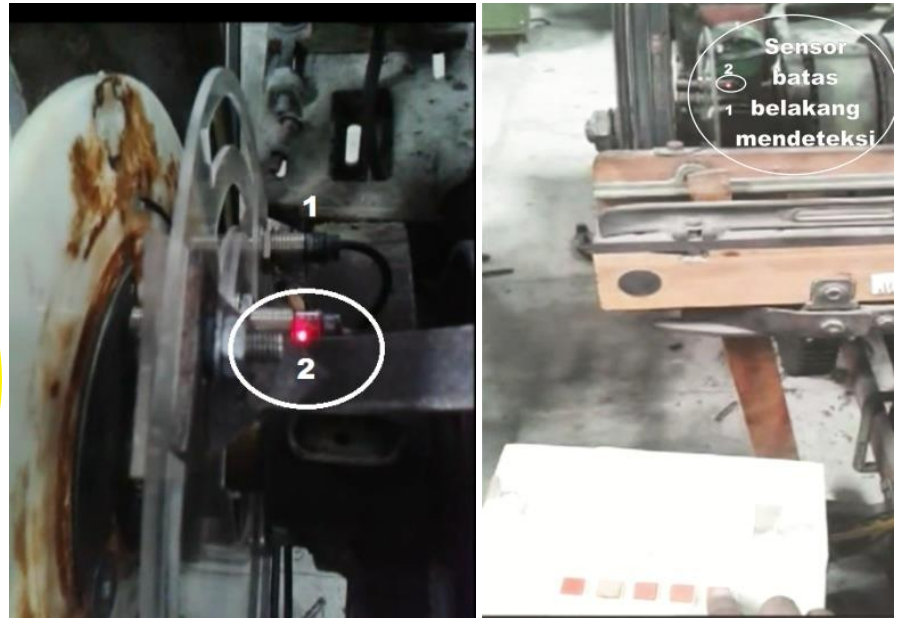

Gambar 12.Gambar nyata dari ilustrasi pertama.

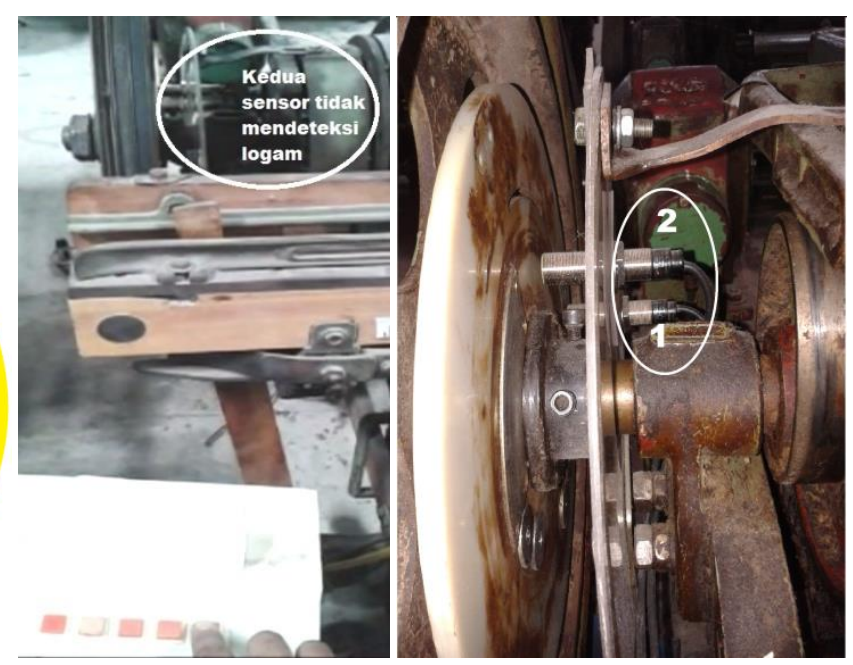

Gambar 14. Gambar nyata ilustrasi kedua.

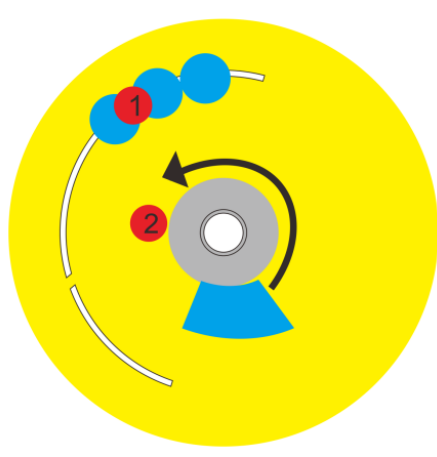

Gambar 15. Ilustrasi ketiga.

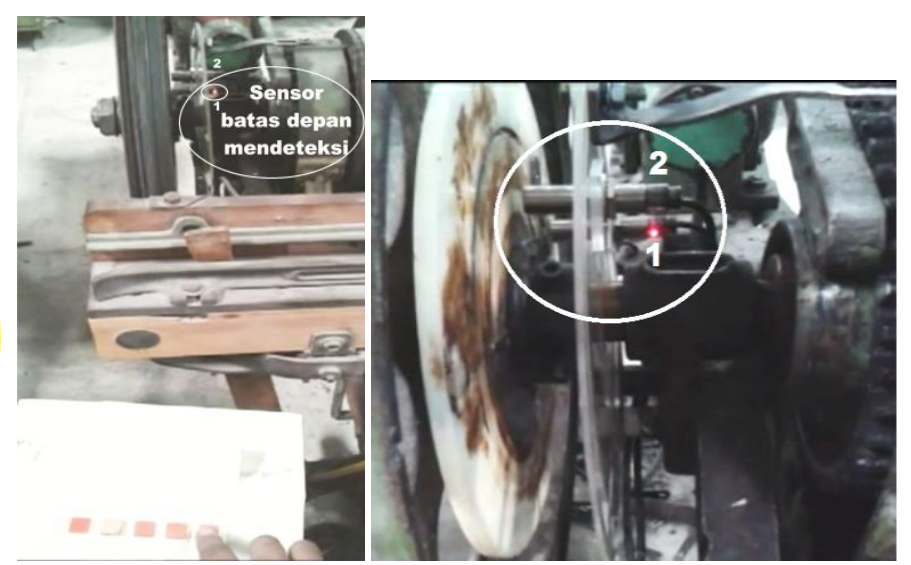

Gambar 16. Gambar nyata ilustrasi ketiga 


\section{Kesimpulan}

Dari hasil pengujian dapat ditarik beberapa kesimpulan antara lain :

1. Sistem dapat bekerja sesuai masukan tombol dari operator.

2. Dalam pengujian yang telah dilakukan sebanyak $30 \mathrm{kali}$, didapatkan prosentase keberhasilan untuk tiap tombol sebagai berikut,
a. Tombol Maju $100 \%$
b. Tombol Mundur $100 \%$
c. Tombol Jogging $100 \%$
d. Tombol Start $100 \%$
e. Tombol Stop $93,33 \%$

3. Tombol Stop didapatkan prosentase 93,33\%, dikarenakan pada saat berhenti masih terlalu maju dari posisi seharusnya. Dalam 30 kali pengujian didapatkan 2 kali kegagalan dalam berhenti.

4. Sistem pengendali yang telah dirancang dapat diterapkan pada mesin tenun GA615 yang terdapat di PT. Panca Bintang Tunggal Sejahtera, namun mikrokontroler masih rawan terkena spike dari induksi motor $A C$ tiga fasa.

\section{Daftar Pustaka}

[1] Anonim, "Cylindrical Type Proximity Sensor." Autonics, pp. 1-6.

[2] Anonim, "8-bit AVR Microcontrollers ATmega328." Atmel Corporation, 1600 Technology Drive, San Jose, CA 95110 USA, pp. 1-444, 2016.

[3] Anonim, "LC1D09M7 - TeSys D contactor - 3P(3 NO) - AC-3 - <= 440 V 9 A - $220 \mathrm{~V}$ AC coil." Schneider Electric, pp. 1-3, 2012.

[4] Arochman, "Alat praktikum pengendali motor induksi tiga fasa untuk hubungan star delta dan berurutan," Tugas Akhir Program Diploma III Teknik Elektro Universitas Negeri Semarang, 2013. 
